\title{
A NEW TAKE ON AN OLD STORY: CHICK LIMB ORGAN CULTURE FOR SKELETAL NICHE DEVELOPMENT AND REGENERATIVE MEDICINE EVALUATION
}

\author{
Emma L. Smith*, Janos M. Kanczler and Richard O.C. Oreffo
}

Bone \& Joint Research Group, Institute of Developmental Sciences, University of Southampton Medical School, Southampton, U.K.

\begin{abstract}
Scientific research and progress, particularly in the drug discovery and regenerative medicine fields, is typically dependent on suitable animal models to develop new and improved clinical therapies for injuries and diseases. In vivo model systems are frequently utilised, but these models are expensive, highly complex and pose a number of ethical considerations leading to the development and use of a number of alternative ex vivo model systems. The ex vivo embryonic chick long bone and limb bud models have been utilised in the scientific research field as a model to understand skeletal development for over eighty years. The rapid development of avian skeletal tissues, coupled with the ease of experimental manipulation, availability of genome sequence and the presence of multiple cell and tissue types has seen such model systems gain significant research interest in the last few years in the tissue engineering field. The models have been explored both as systems for understanding the developmental bone niche and as potential testing tools for tissue engineering strategies for bone repair and regeneration. This review details the evolution of the chick limb organ culture system and presents recent innovative developments and emerging techniques and technologies applied to these models that are aiding our understanding of skeletal developmental and regenerative medicine research and application.
\end{abstract}

Keywords: Chick limb organotypic culture; ex vivo model; embryonic femur; micro-computed tomography; osteogenesis; chondrogenesis; chorioallantoic membrane assay; bone development and regeneration.

*Address for correspondence:

Bone and Joint Research Group

Centre for Human Development, Stem Cells and

Regeneration,

Human Development and Health

Institute of Developmental Sciences

University of Southampton Medical School

Southampton SO16 6YD, U.K.

Telephone Number: +44 2380798664

FAX Number: +44 2380795255

Email: E.L.Smith@soton.ac.uk

www.skeletalstemcells.org

\section{Introduction}

Animal models have long played a crucial role in many aspects of scientific research. In particular, progress in the drug discovery and regenerative medicine fields have benefitted extensively from in vivo animal models in the development of new and improved clinical therapies applied to damaged and diseased tissue. However, in vivo model systems are expensive, highly complex and, critically, present a number of ethical concerns. These considerations have led to the development and use of a number of alternative ex vivo model systems. The presence of multiple cell types located within their natural extracellular matrix and organised in the requisite spatial arrangements found in vivo, make these models highly advanced when compared to the single or dual in vitro cell culture systems. This biology implies the potential to recapitulate a number of in vivo processes, in an experimental system that is cheaper, easier to manipulate experimentally and more acceptable ethically than in vivo systems.

Skeletal-based ex vivo models have been developed in a number of animal species. These include mouse calvarial organ cultures co-cultured with cancer cells as a model of bone metastasis (Curtin et al., 2012), ex vivo sheep perfusion models to study fluid flow and transport processes in loaded bones (Knothe Tate and Knothe, 2000), and ex vivo mandibular organ cultures using either rat or mouse tissue to assess bone repair processes or inflammatory bone pathology respectively (Sloan et al., 2012; Smith et al., 2010). The chick embryo, which represents an economical and accessible in vivo and ex vivo model has been utilised for almost a century in the developmental biology field and is now becoming increasingly recognised as a viable model system in a number of scientific research fields, including the disciplines of skeletal tissue engineering and regenerative medicine.

The chick embryo has been a major and established model system in developmental biology for many years, indeed even since the early days of Aristotle, as reviewed in a number of papers (Stern, 2004; Tickle, 2004; Wolpert, 2004). These studies in the chick embryo suggest an archaic model, not for the modern high throughput molecular screening techniques of today. However the avian embryo is well characterised with a fully sequenced genome (Hamburger and Hamilton, 1992; Hillier et al., 2004), is highly cost-effective, and experimentally accessible for manipulation in ovo (Rashidi and Sottile, 2009). Importantly, the ex vivo chick system provides a model without an immune system in early development 
making it attractive for tissue/cell xenotransplantation (Boulland et al., 2010; Goldstein, 2006; Wichterle et al., 2008). It is also possible to utilise transgenesis techniques in embryos, one particular example being the development of green fluorescent protein (GFP)-expressing transgenic chicks (Kwon et al., 2004; McGrew et al., 2004; Sang, 2004). As such, the avian model system has made significant scientific contributions, not just to the field of developmental biology, but also to immunology, genetics, virology, cancer, cell biology and tissue engineering, as reviewed by Stern (2005). The rapid development of avian skeletal tissues coupled with the ease of experimental manipulation has also seen such model systems used widely in the skeletal biology research field, in particular in the development of alternative tissue engineering strategies to augment bone repair and regeneration. This article reports on the evolution of the chick limb organ culture systems and current developments in technologies and applications of the model that are currently informing skeletal development and regeneration.

\section{Evolution of the chick limb organ culture systems}

Embryonic chick long bones and limb buds were utilised over 80 years ago by Dame Honor Fell, who pioneered the development of the 'watch-glass' method of culturing whole embryonic limb buds and long bones from chick embryos in ex vivo organ cultures (Fell and Robison, 1929). Isolated embryonic chick limb buds and femora were cultured in media contained inside a watch-glass, placed in a Petri dish on a layer of moist cotton wool. This in essence provided a humidified chamber and enabled analysis of the growth, development and phosphatase activity of the cultured chick limbs. This model system led to seminal observations, including the functions of bone cells and the role of exogenous factors in skeletal function. A particular attraction of this system is that both cells and matrix are maintained within their in vivo orientation and thus the cell-cell and cell-matrix interactions, important for maintaining the differentiated state of the cells, are preserved (Hall, 1981). An additional advantage is the ability to maintain cultures in the absence of foetal calf serum (FCS), which, indeed in organotypic cultures, tends to decrease cell proliferation, increase abnormal secondary cartilage growth and ectopic mineralisation, and can also cause migration of cells out of the whole femur onto the culture apparatus (Bingham and Raisz, 1974; Roach, 1990). The absence of undefined and batch variable FCS allows much greater chemical definition, and thus this early model system of bone development was further utilised by Fell, Mellanby and Dingle (Fell, 1969) in seminal studies to analyse the impacts of vitamin A excess (Dingle et al., 1961; Fell and Mellanby, 1952), complement antiserum (Fell et al., 1966) and hydrocortisone (Weissmann and Dingle, 1961) in chick limb bones.

In 1969, a system was developed in which isolated chick embryonic long bones were cultured on a stainless steel mesh within small flat-bottomed dishes (Fell and Dingle, 1969). $1.5 \mathrm{~mL}$ media was added to each dish, sufficient to wet the mesh surface and enable the bones to be cultured at the liquid-gas interface. The air-liquid interface has since been discovered to be important for increasing oxygen tension within the tissue, promoting higher viability and capacity for bone formation (Smith et al., 2010). Using this approach, bone tissue was cultured for up to $8 \mathrm{~d}$ to allow the analysis of sugar endocytosis in skeletal tissues. Interestingly, the bones were rotated every $48 \mathrm{~h}$, which does not occur in the modern day chick limb organ culture systems, since it is thought that the forces applied to the limb through interactions with the semiporous membrane are important in maintaining structured, ordered bone growth (Kanczler et al., 2012).

Fell and Dingle's 1969 method for organotypic culture provided, for over twenty years, a method of exploring embryonic skeletal development. This was used to demonstrate the presence of cathepsin D in femur and tibia cartilage (Poole et al., 1974; Weston et al., 1969), as well as to assess the effects of retinol and retinol-binding protein on skeletal development in chick limb bone rudiments (Dingle et al., 1972). In 1990, the model was further developed with the work of Dr. Helmtrud Roach, who altered the cultures to incorporate a semi-porous filter paper membrane on top of the stainless steel mesh and decreased the length between media changes from $48 \mathrm{~h}$ to $24 \mathrm{~h}$, a process shown to avoid media acidification due to waste products (Roach, 1990). This approach allowed further characterisation of many aspects of the chick bone culture system, including the growth and resorption of cartilage and bone tissue, mineralisation, the effects of FCS, and the stages of growth (and subsequent deterioration) over the course of these long-term cultures (Roach, 1992a; Roach, 1990; Roach, 1997; Roach, 1992b; Roach et al., 1995) (Table 1). During the first 2 days of culture, femora recovered from tissue damage sustained during dissection, while days 3-9 of culture were identified as optimal for cell proliferation and steady growth of bone and cartilage tissue. Although femur cultures can be maintained for up to $18 \mathrm{~d}$ ex vivo, a deterioration period begins after the optimal culture period resulting in cell necrosis and tissue dissolution, and therefore a standard culture period of $8-10 \mathrm{~d}$ is utilised in the ex vivo femur cultures of today.

\section{Chick limb organ culture systems for tissue engineering}

The current chick limb organ culture system remains comparable to established models, although the stainless steel mesh of previous experiments has been replaced with cell culture inserts - plastic pre-made sterile dishes containing a semi-porous polycarbonate membrane (Fig. 1). In addition, current experiments primarily focus on femora from embryonic day 11 (E11) chicks, rather than older aged embryos, since these immature, cartilaginous femora display a high number of undifferentiated progenitor cells and thus offer far greater potential for experimental manipulation, particularly in terms of inducing formation of skeletal tissue. As indicated above, to study skeletal development an optimal standard culture period of $8-10 \mathrm{~d}$ is utilised. The immature embryonic day 11 femora, which are undergoing rapid growth at this 
Table 1. Summary of the characterisation of the ex vivo chick organ culture system; adapted from (Roach, 1990; Roach, 1997; Roach et al., 1995).

\begin{tabular}{|c|c|}
\hline Test & Observation \\
\hline $\begin{array}{l}\text { Ex vivo bone growth and } \\
\text { resorption }\end{array}$ & $\begin{array}{l}\text { - New osteoid matrix secreted by osteoblasts in trabecular spaces and beneath the } \\
\text { periosteum. } \\
\text { - } \\
\text { - } \quad \text { Lultidirectional apposition rather than the unidirectional observed in ovo. } \\
\text { - }\end{array}$ \\
\hline $\begin{array}{l}\text { Ex vivo cartilage growth and } \\
\text { resorption }\end{array}$ & $\begin{array}{l}\text { - } \quad \text { Proliferation and maturation occurred ex vivo, similar to observed in ovo. } \\
\text { - Abnormal formation of secondary cartilage was occasionally observed, increased in } \\
\text { presence of foetal calf serum (FCS) and in submerged non-organotypic cultures. } \\
\text { - Some chondrocyte populations were able to 'switch' to osteogenic cells. } \\
\text { - Cartilage resorption lost over culture period, due to loss of mononuclear phagocytes. }\end{array}$ \\
\hline Ex vivo mineralisation & $\begin{array}{l}\text { - Only effective way to induce mineralisation ex vivo was to add calcium } \\
\beta \text {-glycerophosphate (but this could cause ectopic calcification). }\end{array}$ \\
\hline Effects of FCS in culture & $\begin{array}{l}\text { Osteogenic and chondrogenic cells proliferated and differentiated throughout culture } \\
\text { in serum-free media. } \\
\text { - FCS decreased rates of }\left[{ }^{3} \mathrm{H}\right] \text { thymidine uptake, and increased abnormal growth of } \\
\text { secondary cartilage and ectopic calcification. } \\
\text { - Therefore FCS considered disadvantageous in the ex vivo chick model. }\end{array}$ \\
\hline $\begin{array}{l}\text { Ex vivo stages of growth and } \\
\text { deterioration }\end{array}$ & $\begin{array}{l}\text { Three stages: } \\
\text { - Adaptation: Femurs adjusted to culture conditions following trauma of dissection. } \\
\text { Lasted approximately } 2 \text { days. } \\
\text { - Steady growth: Low tissue breakdown with occurrence of cellular proliferation and } \\
\text { differentiation. Lasted at least } 9 \text { days. } \\
\text { - Deterioration: Cell necrosis and tissue dissolution. }\end{array}$ \\
\hline
\end{tabular}

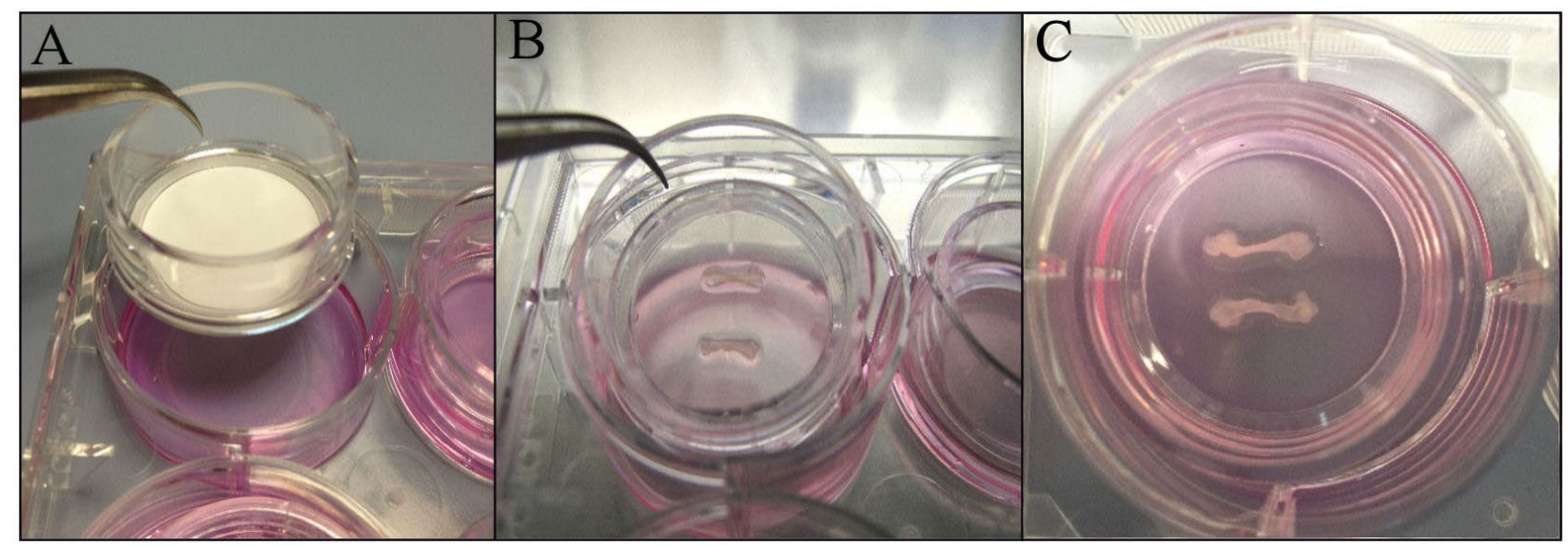

Fig. 1. Setup of the organotypic chick femur culture system. The figure shows the semi-porous (pore size $0.4 \mu \mathrm{m}$ ) polycarbonate membrane with $1 \mathrm{~mL}$ media beneath $\mathbf{( A )}$ onto which freshly isolated paired chick femora are placed (B) and cultured at the liquid-gas interface for $10 \mathrm{~d}$ (C).

time in ovo, show high levels of cellular proliferation and subsequent tissue formation, and thus the culture period is sufficient to demonstrate significant formation of both bone and cartilage matrix in response to exogenous stimuli. Characterisation of the tissue and cellular behaviour in response to chondrogenic and osteogenic media components indicated this capability of the ex vivo femora to respond differentially to set stimuli. Osteogenic media compounds, such as dexamethasone, significantly increased bone tissue and associated markers, while chondrogenic compounds increased markers of chondrogenesis and reduced the amount of bone tissue within the femora, as assessed by micro-computed tomography $(\mu \mathrm{CT})$ and histological/ immunohistochemical analysis (Kanczler et al., 2012). The use of virtual microscopy scanning technology enables detailed examination of histological sections at the macroscopic, microscopic and single cell level (Fig. 2). The responsiveness of the tissue in combination with relatively low cost (allowing for a large number of experimental repeats), the ease of experimental manipulation, and the potential in terms of the 3 Rs of replacement, reduction and refinement has resulted in the wide application of the chick femur model system as detailed below.

\section{Ex vivo chick femur applications for toxicology}

\section{Screening and toxicology testing}

The capabilities of the ex vivo chick femur model to respond differentially and uniquely to exogenous stimuli provides an attractive model for testing growth factors and screening small molecules. The model has been used to demonstrate the negative feedback loop that exists between Indian hedgehog and parathyroid hormone-related protein 


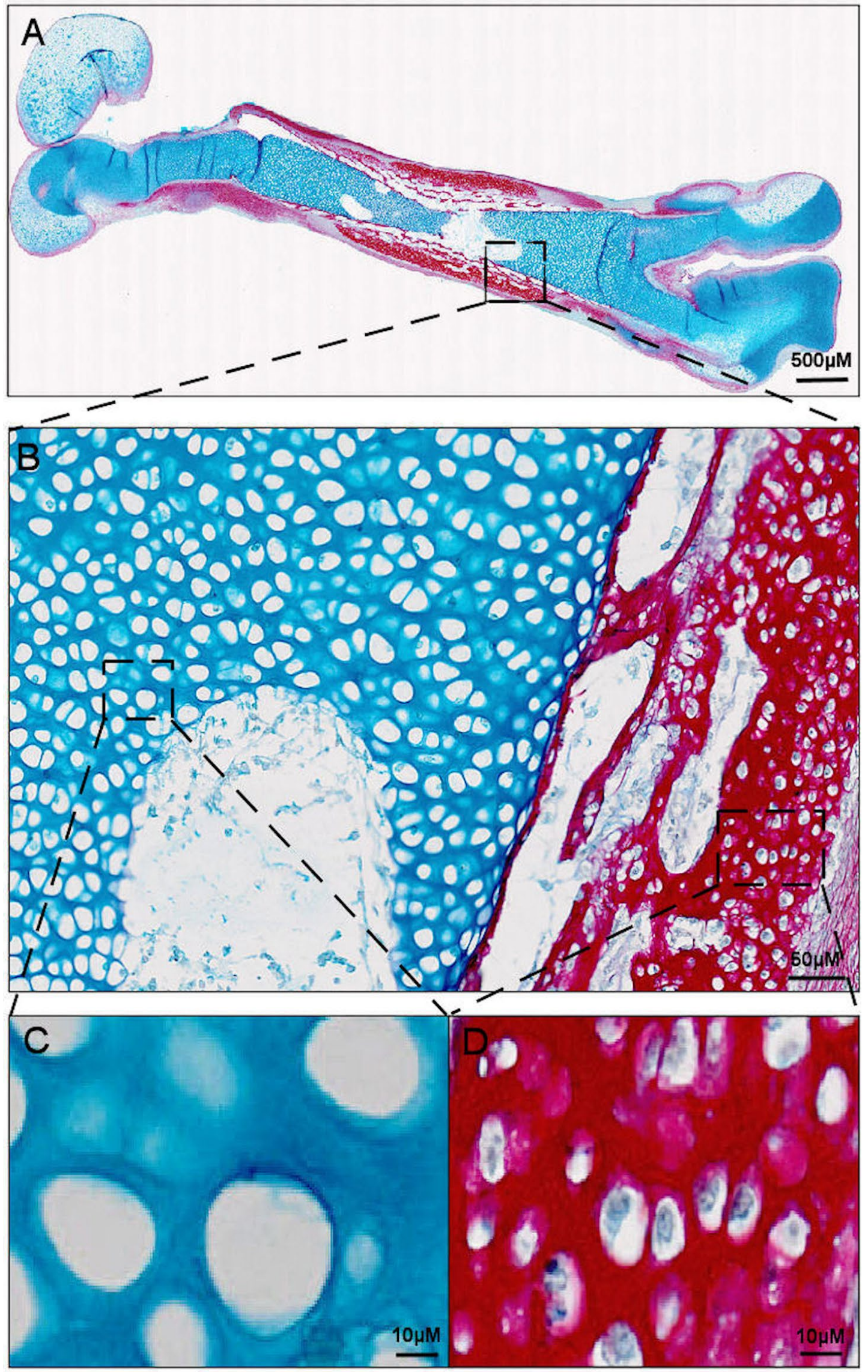

Fig. 2. Digital virtual scanning microscopy enables detailed histological analysis of chick femur tissue sections at the macroscopic, microscopic and single cell level. (A) Whole mount femur section. (B) Microscopic detail of bone, cartilage and marrow spaces. (C) Single chondrocyte lacunae within the hypertrophic cartilage region. (D) Osteocytes within the bone matrix. 

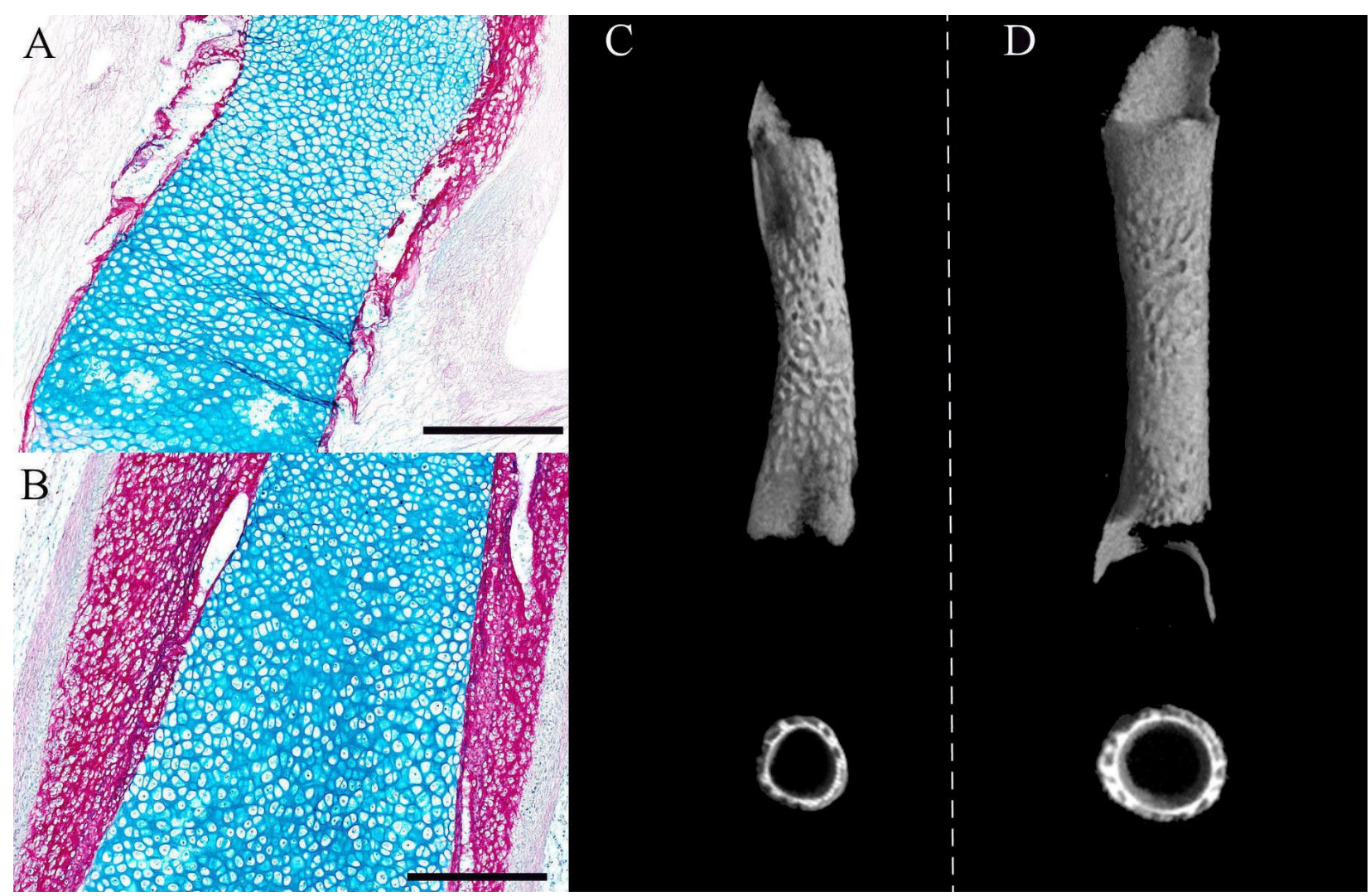

Fig. 3. Responsiveness of ex vivo chick femora to exogenous stimuli. (A) Bone matrix formation was significantly reduced in E11 chick femora cultured with $15 \mathrm{ng} / \mathrm{mL}$ TGF- $\beta 3$ compared to (B) femora cultured in basal media alone. $\mu \mathrm{CT}$ data indicated (C) a shorter, thinner bone collar in TGF- $\beta 3$ stimulated femora compared to (D) basal cultured femora. Scale bar $=200 \mu \mathrm{m}$.

(Minina et al., 2001) and to analyse transforming growth factor (TGF) signalling in limb development (Lorda-Diez et al., 2010). Recent studies have also assessed the effects of exogenous growth factors on skeletal tissue formation. Initial stimulation of ex vivo chick femora with exogenous growth factors alone demonstrated the chondrogenic effects of TGF- $\beta 3$ (Fig. 3) (Smith et al., unpublished data). There was a significant reduction in the amount of bone tissue within the femora treated with TGF- $\beta 3$ compared to basal cultured controls, as assessed by $\mu \mathrm{CT}$ which demonstrated a reduction in a number of bone volume and structural parameters and histological analysis which demonstrated decreases in bone matrix and bone marker expression such as collagen type I. The data correlated with subsequent increases in markers of chondrogenesis, including collagen type II and tissue glycosaminoglycan content. In contrast to the chondrogenic effects of TGF- $\beta 3$, addition of exogenous parathyroid hormone and parathyroid hormone-related protein to the femur cultures in a non-continuous manner significantly enhanced osteogenesis, with $\mu \mathrm{CT}$ demonstrating significant increases in bone tissue and histological analysis revealing increases in associated marker expression, such as collagen type I and STRO-1, together with increased cell proliferation (Smith et al., 2012). The model therefore has potential to provide crucial information on appropriate growth factor application for developing and informing clinical skeletal regeneration strategies.

\section{Developmental biology applications: microinjection of distinct cell populations}

Micromanipulation and microinjection techniques have been utilised in a number of chick in ovo and in vitro models, primarily to examine and delineate mechanisms of embryonic development (Rashidi and Sottile, 2009). In ovo microinjection techniques were used as early as 1981 to assess the formation of embryonic chick mesonephric nephrons (Friebova-Zemanova, 1981) and, more recently, to assess formation of the precisely patterned axonal connections that are required for proper movement of the vertebrate eye (Lance-Jones et al., 2012). Microinjections of specific substances, to either enhance or inhibit a particular signalling or differentiation pathway, have also been used in a number of studies. Microinjection of exogenous platelet-derived growth factor (PDGF), or a PDGF inhibitor, demonstrated the role of this growth factor in derivation of the peripheral nervous system of the head (McCabe and Bronner-Fraser, 2008). Microinjection of glycosaminoglycan-degrading enzymes enabled assessment of the role of GAGs in the morphology of the embryonic mesoblast, to demonstrate that hyaluronate is involved in preserving the mesenchymal aspect of the middle layer during lateral cell migration (Van Hoof et al., 1986). Ganan et al. (1993) examined the microinjection of substances that induce interdigital chondrogenesis in order to assess the phenomenon of embryonic extra digit formation. Microinjection techniques have also 


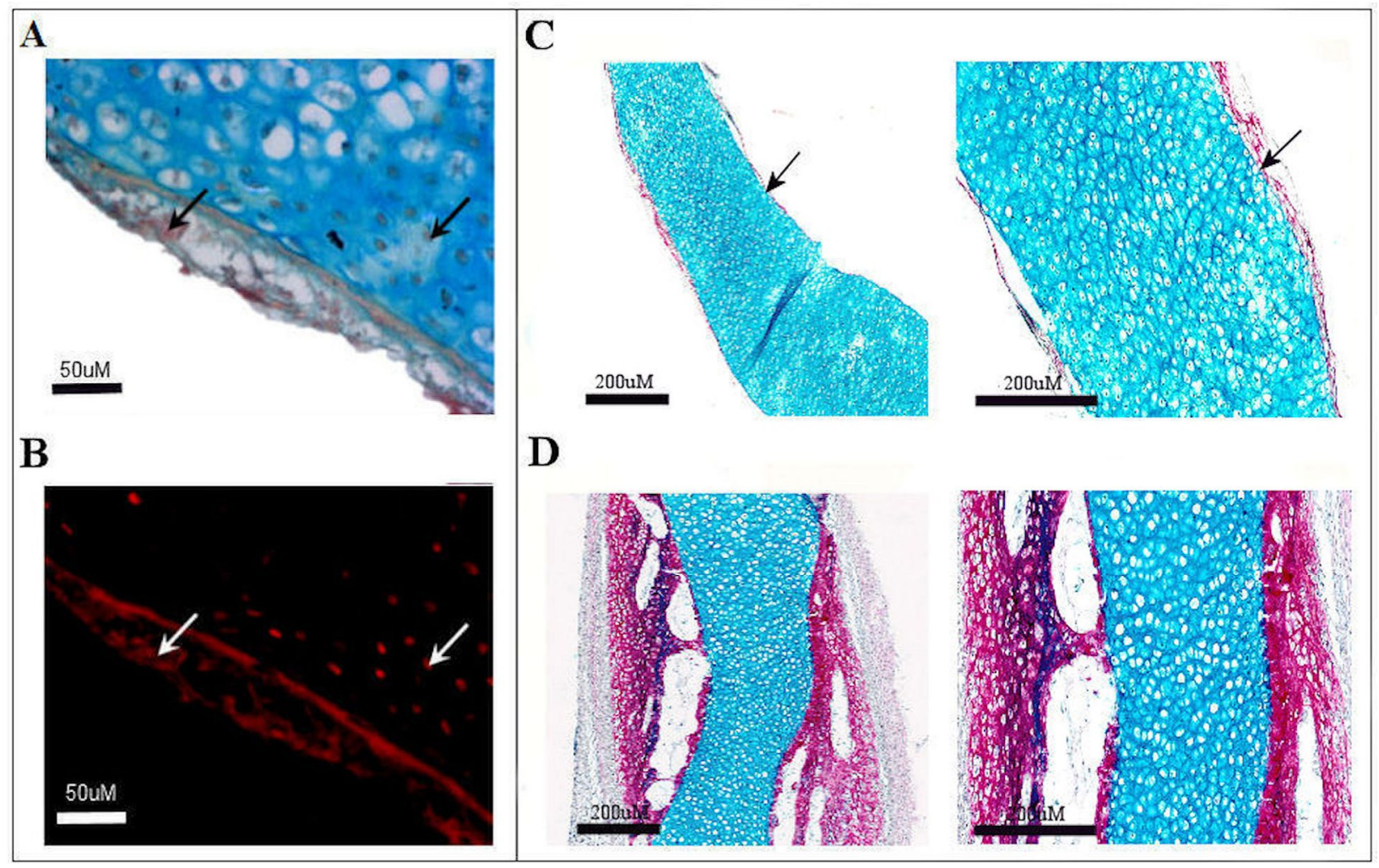

Fig. 4. Microinjection of preosteoclast cell populations into ex vivo chick femora. (A) Tartrate-resistant acid phosphatase (TRAP) activity of injected preosteoclast cells and (B) corresponding PKH26 fluorescent cell tracker. Arrows indicate TRAP activity and corresponding PKH26 dye. Scale bars $=50 \mu \mathrm{m}$. (C) Bone resorption in chick femora injected with preosteoclasts and stimulated with PTH compared to (D) femora with sham PBS injection. Arrows indicate areas of decreased bone matrix. Scale bars $=200 \mu \mathrm{m}$.

been combined with RNA technologies, such as injection of short hairpin RNA (shRNA) to produce targeted knockdown of specific proteins (Nagchowdhuri et al., 2012), or injection of heterospecific messenger RNAs to study their translation in living cells (Stacey and Allfrey, 1976). In addition, McKinney and Kulesa (2011) used in ovo micromanipulation techniques to examine calcium dynamics within the neural crest - a novel application using the genetically encoded calcium indicator GCaMP3 that has the potential to elucidate mechanisms underlying complex cell migration and patterning events that occur during embryogenesis.

The facile nature of avian embryo culture and manipulation in ovo makes micromanipulation an attractive tool. Indeed, microinjection techniques can also be applied to the ex vivo femur model. The ability to inject a distinct population of cells, that would not normally reside in the femur tissue, presents a unique opportunity to assess tissue developmental processes. We have recently demonstrated that injection of chick preosteoclast cell populations (not normally present in the immature chick tissue in ovo) can induce significant bone resorption and modelling processes within the femur tissue, when stimulated with factors known to be involved in bone resorption and remodelling in vivo such as $\mathrm{PTH}$ and $\mathrm{PTHrP}$ (O'Brien et al., 2008; Schlüter, 1999; Silva et al., 2011) (Fig. 4) (Smith et al., unpublished data). Injection of other distinct cell types enable assessment of alternative developmental processes within an ex vivo setting, such as injection of endothelial or inflammatory cells to assess vascularisation or inflammation, respectively. In addition, application of microinjection can be further extended to biomaterials such as, for example, scaffold microparticles which can be injected into distinct localised sites within the chick femora, in combination with cell types or exogenous growth factors. This approach enables analysis of parameters such as toxicity, cell response and tissue response to a biomaterial, alongside an internal control constituted by biomaterialfree regions of the tissue.

\section{Understanding angiogenesis utilising chorioallantoic membrane cultures}

A relatively recent modification of the ex vivo chick femur model has been to couple the model with the chick chorioallantoic membrane (CAM) culture system (Green et al., 2004; Salem et al., 2003; Takahashi et al., 1991; Yang et al., 2004). The CAM, an extraembryonic membrane that mediates both gas and nutrient exchanges within the chick embryo, is highly vascularised with a dense capillary network. In addition, the CAM model allows exogenous materials to be implanted without issues of material rejection, since the immune system of the chick embryo is not fully developed. As such, it has been used extensively as a model system to study angiogenesis in a variety of scientific research fields, including oncology, obstetrics, pharmacology/pharmaceuticals and even veterinary oncology. A large number of studies have utilised the CAM system as a model for angiogenesis 


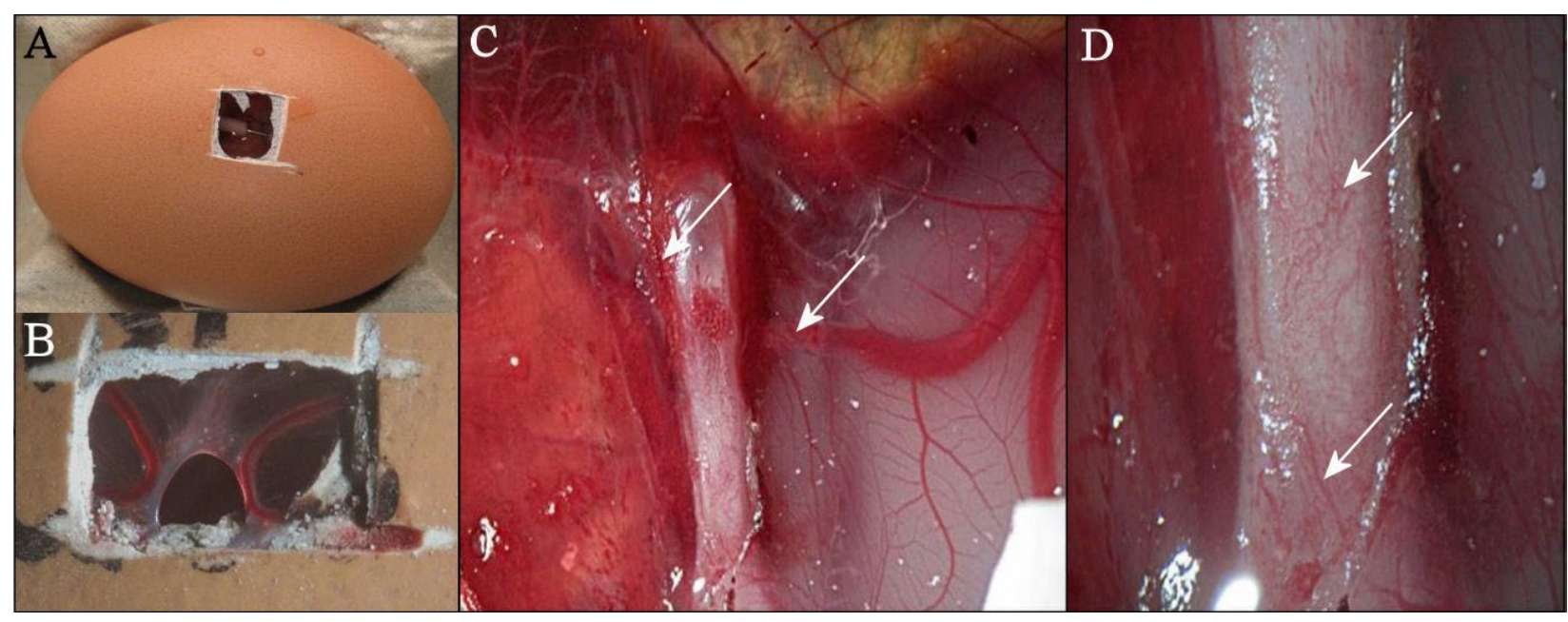

Fig. 5. Setup of the CAM culture system. (A) Window prepared in embryonic chick egg shell into which the ex vivo chick femur is placed onto the chorioallantoic membrane beneath. (B) Demonstration of chick membranes covering the window after $7 \mathrm{~d}$ of incubation in a $38{ }^{\circ} \mathrm{C}$ Hatchmaster incubator. (C, D) Blood vessels surrounding the chick femur (indicated by arrows) after $7 \mathrm{~d}$ in CAM culture.

Supplementary Video S1 (To be found on the web page of the paper). Demonstration of viable chick embryo movement and blood vessel presence during $7 \mathrm{~d}$ CAM culture.

and/or anti-angiogenesis in the context of cancer, for the development or testing of anti-angiogenic drugs aimed at treating certain cancers where enhanced angiogenesis is a key feature (Chen et al., 2010; Ribatti, 2008a; Ribatti, 2008b; Tufan and Satiroglu-Tufan, 2005). Two such studies have examined the use of antibodies to block the angiogenic endocrine gland-related vascular endothelial growth factor (EG-VEGF), which led to disruption of the vasculature and extravasation of red blood cells (Feflea et al., 2012) and the potent anti-angiogenic effects of a heparin modified endostatin (Ning et al., 2012).

The CAM assay has also been utilised as a culture method and screening tool. Culturing of xenotransplanted sarcomas on the membrane surface illustrates the potential for the use of CAM as a prognostic and predictive preclinical model (Sys et al., 2012), while CAM culture of ovarian cancer cells enabled assessment of their metastatic properties as well as the effects on the cells of potential therapeutic agents (Lokman et al., 2012). In addition, culture of cryopreserved ovarian tissue on the CAM has been used to assess the quality of cryopreservation of ovarian tissue before cancer therapy and prior to reimplantation (Isachenko et al., 2012). The CAM culture system has also been used in the veterinary field, in a novel model to derive and cultivate a feline vaccine-associated sarcoma cell line (Zabielska et al., 2012).

Within skeletal tissue engineering, the CAM culture system has been widely used to assess angiogenesis, since insufficient vascularisation within bone grafts leading to a necrotic core remains a central unmet challenge for bone tissue regeneration. The CAM system has proved to be an effective method of confirming the angiogenic properties of novel scaffold materials, with or without cells or angiogenic factors, for potential application in critical size bone grafts as well as for assessing the susceptibility of these materials to vessel invasion (Baiguera et al., 2012; Borges et al., 2003; Kanczler et al., 2007). Exemplar studies include: the testing of 45S5 Bioglass-derived glass-ceramic scaffolds for biocompatibility and bone induction (Vargas et al., 2009); spheroidal osteoblast and endothelial cell cocultures for induction of perfused blood vessel networks into scaffolds (Steffens et al., 2009); porous polycaprolactone (PCL) scaffolds incorporating VEGF for stimulation of angiogenesis (Singh et al., 2012); and DegraPol ${ }^{\circledR}$ foam scaffolds seeded with human osteoblasts and endothelial cells for angiogenic induction (Buschmann et al., 2011). The CAM model has also been used to demonstrate the potential of functionalised self-assembling peptide scaffolds, to provide microenvironments for migration of endothelial cells leading to increased angiogenesis (Liu et al., 2012), and the osteoconductivity and vascularisation of an electrospun nanocomposite based on poly-lacticco-glycolic acid and amorphous calcium phosphate nanoparticles (PLGA/a-CaP) seeded with human adiposederived stem cells (Buschmann et al., 2012).

\section{Bio-imaging technology development and organ culture}

The development of additional imaging techniques, such as magnetic resonance imaging (MRI), allow better resolution and quantification of angiogenic responses (Chesnick et al., 2011). Combination of the CAM model system with the ex vivo chick femur model as described above, allow for longitudinal assessments of angiogenesis and vessel invasion into the femora in response to exogenous growth factors or scaffold materials using time-lapse photography (Fig. 5, Supplementary video S1 - available on the paper's webpage). This provides a closer approximation of the in vivo situation and enables angiogenic processes and blood vessel formation to be studied in a dynamic ex vivo setting, reducing the requirement for large numbers of in vivo experimental studies (Eder et al., 2006; Falkner et al., 2004). 
A

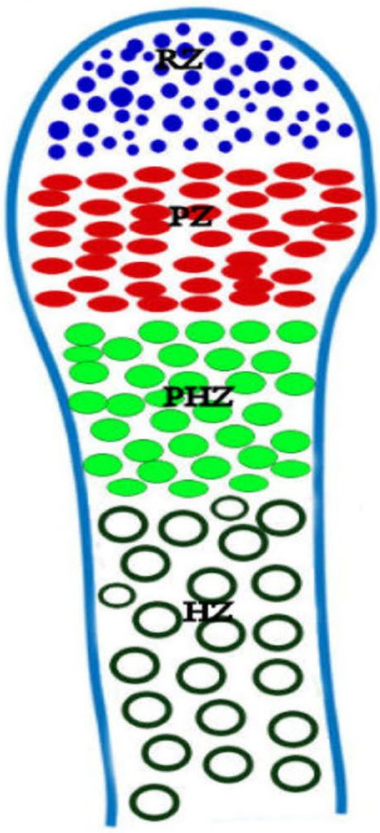

B

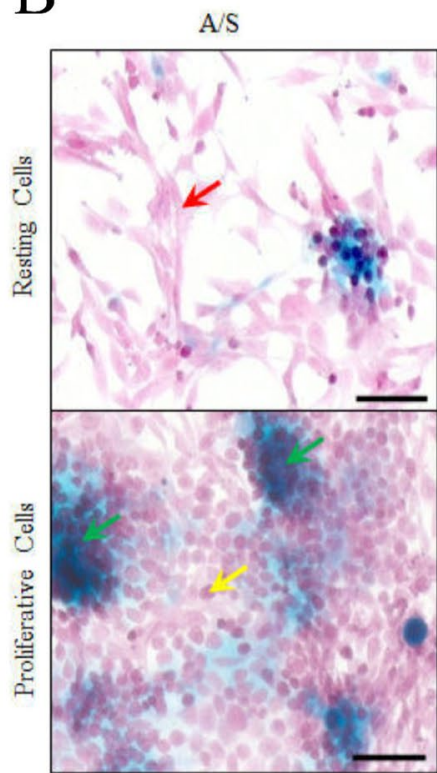

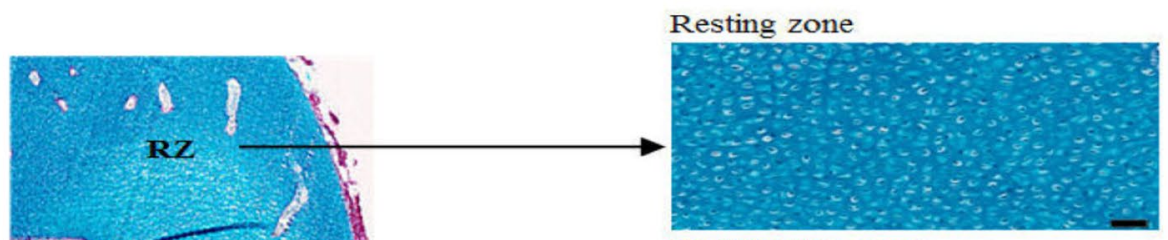

Proliferative zone

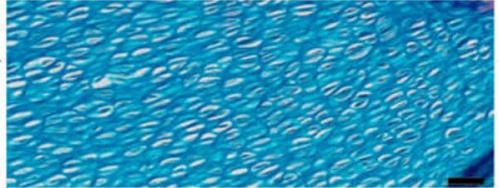

Prehypertrophic zone

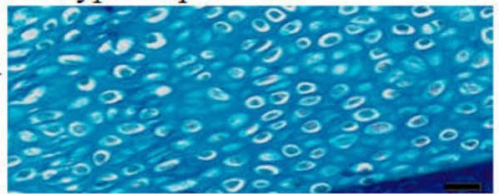

Hypertrophic zone

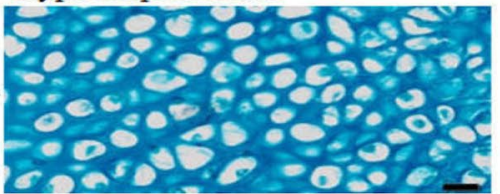

Col II

$\operatorname{Col} \mathrm{X}$

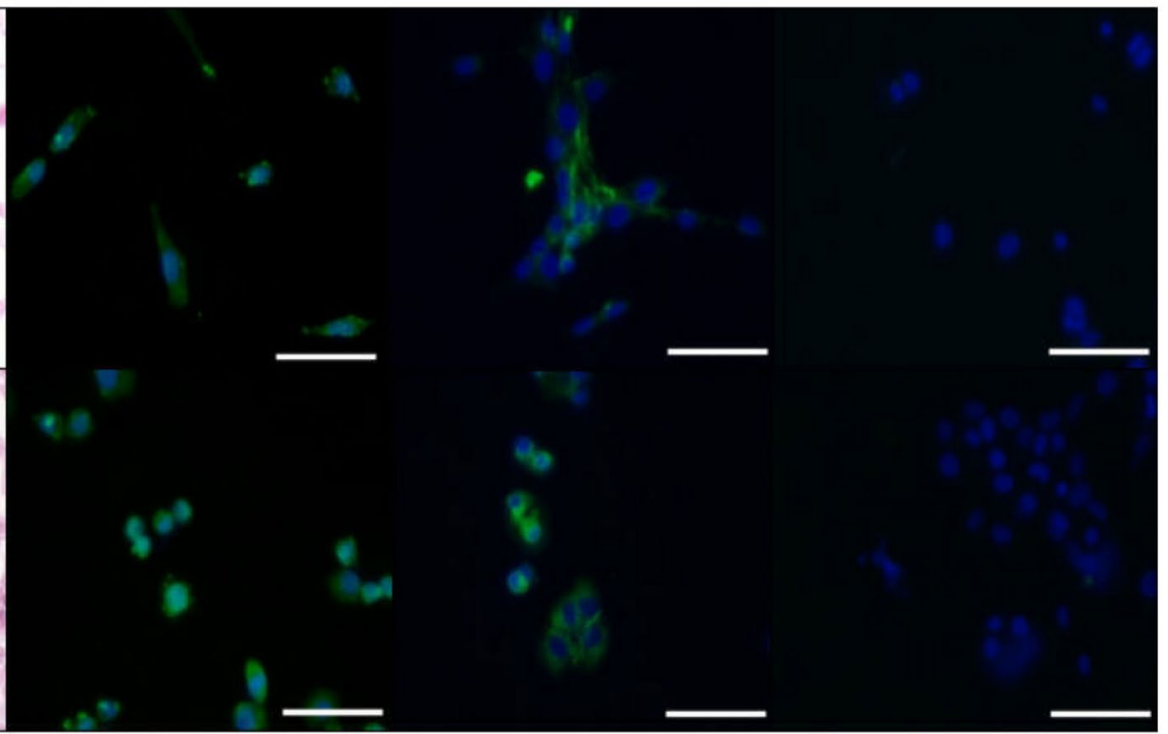

Fig. 6. (A) Representation of the embryonic day 16 avian growth plate structure consisting of resting zone (RZ), proliferative zone (PZ), prehypertrophic zone (PHZ) and hypertrophic zone (HZ) cells. Scale bar $=20 \mu \mathrm{m}$. (B) Expression profile of in vitro cells isolated from the resting zone (top) or proliferative zone (bottom) stained for alcian blue/Sirius red (A/S), proliferating cell nuclear antigen (PCNA), collagen type II and collagen type X. Red arrows indicate fibroblastic morphology of resting zone cells, while yellow and green arrows indicate small, round proliferative zone cells expressing material staining with alcian blue. Scale bar $=50 \mu \mathrm{m}$.

\section{Mechanobiology}

Assessment of mechanical forces using bioreactor technology

One obvious drawback to using an ex vivo model system over in vivo approaches for bone development and repair processes is the absence of the mechanical forces which are so crucial for bone development in vivo. Cells are permanently subjected to a wide variety of mechanical, chemical and electrical stimuli in vivo that can influence their behaviour in a variety of ways. The absence of these forces in static in vitro and ex vivo conditions can alter natural cellular behaviour and, in the context of tissue engineering, impede the development of a functional tissue (Bilodeau and Mantovani, 2006; Salgado et al., 2004).

The development of bioreactor technology has enabled the simulation of in vivo mechanical forces in in vitro and ex vivo model environments, as well as improving the 
perfusion of nutrients throughout the tissue (Bilodeau and Mantovani, 2006; Butler et al., 2000; David et al., 2008; El Haj and Cartmell, 2010; Mauney et al., 2004; Yu et al., 2004). A wide variety of bioreactor types exist that include rotating oxygen-diffusing vessels, filled with culture media, and perfusion systems incorporating controlled flow back and forth within the construct. These systems have been shown to increase cell proliferation and enhance osteoblast differentiation/osteogenesis (Botchwey et al., 2001; Granet et al., 1998; Kavlock and Goldstein, 2008; Milan et al., 2009; Pound et al., 2006; Sikavitsas et al., 2003). In addition, perfusion systems can be combined with application of mechanical forces using compression bioreactors to maintain viable bone explants (El Haj et al., 1990) and significantly increase osteogenesis in cell-seeded scaffolds (Bolgen et al., 2008). Recent developments have seen the use of magnetic force bioreactors, which apply forces directly to the cell membrane itself, rather than the surrounding scaffold, through the use of cell-attached magnetic nanoparticles. Magnetic force bioreactors are capable of increasing expression of bone matrix proteins and enhancing osteogenic differentiation (Bock et al., 2010; Cartmell et al., 2002; Dobson et al., 2006; Hughes et al., 2007; Kanczler et al., 2010). As well as mechanically stimulating scaffolds, cells and bone explants, bioreactor technologies can be adapted for use in the chick femur system, enabling application of forces across the ex vivo tissue to provide a closer approximation of the model to the in vivo environment. A recent study using a custommade bioreactor system, developed to apply forces across the organotypic culture system, demonstrated an increase in bone growth and mineralisation within ex vivo chick femora that had cyclic, but not static, hydrostatic pressure applied to them (Henstock et al., 2013).

\section{Tissue Regeneration}

\section{Assessment of bone repair using a chick defect model} The ex vivo chick femur model can be manipulated to provide a tissue reparation model by applying defects to the bone or cartilage tissue. These could include wedge defects, drill defects and critical sized defects (Gellynck et al., 2007; Green et al., 2004; Salem et al., 2003). The creation of such defects allows the response of cells and tissues proximal to the defect site to be assessed and the efficacy of regenerative interventions such as scaffolds, cells, growth factors etc. for facilitating the skeletal repair processes.

As discussed above, a particular strength of this model is the presence of multiple cell and tissue types that enables simultaneous analysis of the three key processes underlying skeletal repair: osteogenesis, chondrogenesis and, in combination with the CAM model, angiogenesis. For example, Salem et al. (2003) used a chick femur wedge defect model to demonstrate the biocompatibility of a self-assembling injectable porous scaffold that had potential uses in bone tissue engineering therapies. The same wedge defect model was also utilised to demonstrate the biocompatibility and angiogenic activity of calcium carbonate microspheres seeded with human bone marrow stromal cells (Green et al., 2004). Gellynck et al. (2007) also demonstrated the potent osteogenic effects of the bone agonist purmorphamine, an activator of the Hedgehog pathway, by seeding chick femur drill-defects with purmorphamine-coated hydroxyapatite beads.

\section{Application of cell populations to enhance skeletal repair in chick femora}

As well as injecting exogenous populations of cells into the chick femora to examine specific processes, it is also possible to isolate endogenous cell populations from within the femora themselves. Isolated cell populations can be examined in vitro or, in combination with micromanipulation techniques, re-implanted into different loci within the femur tissue providing an opportunity to dissect specific mechanisms in cell behaviour, interactions and signalling. We have examined cell isolation from the growth plate regions of chick femora, specifically looking at the resting and proliferative zone regions where highly proliferative progenitor cells reside (Fig. 6A). Isolated cells from these individual zones of the avian growth plate exhibit unique morphologies and protein expression (Fig. 6B). Resting zone cells exhibit a fibroblastic morphology, while cells isolated from the proliferative zone display a small, rounded phenotype and express alcian blue-staining material. Both cell types express the proliferation marker PCNA (proliferating cell nuclear antigen) and the cartilage marker collagen type II, but neither expresses collagen type $\mathrm{X}$, a marker of chondrocyte hypertrophy. Furthermore, implantation of whole growth plate regions into a chickfemur defect model indicates the presence of directional cues within the growth plate that enable ordered directional bone growth in vivo. For example, implantation of either the resting zone region or the proliferative zone region into a central chick-femur defect initiates host tissue integration on only one side of the defect depending on the orientation of the implanted growth plate region (Fig. 7). Removal of growth plate cells from within their natural extracellular matrix disrupts this directional response with host tissue integration at both sides and a strong host periosteal induction (Smith et al., unpublished data).

The chick femur model also presents an opportunity for studying mechanisms of niche development and stem cell fate. Analysis of the mesenchymal stem cell marker STRO-1 indicates a defined and ordered spatio-temporal expression pattern throughout embryonic development of the chick femur (Fig. 8). STRO-1 expression is virtually absent within immature cartilaginous embryonic day 10 femora, but begins to appear within the diaphyseal bone collar at embryonic day 11. Expression increases significantly within the developing bone and marrow spaces over the next few days of development until embryonic day 15, after which expression is again reduced and is predominantly restricted to marrow spaces.

\section{Limitations of chick femur organ culture}

Despite the many advantages of ex vivo chick femur organ cultures, including low cost, ease of experimental manipulation, rapid development and the presence of 

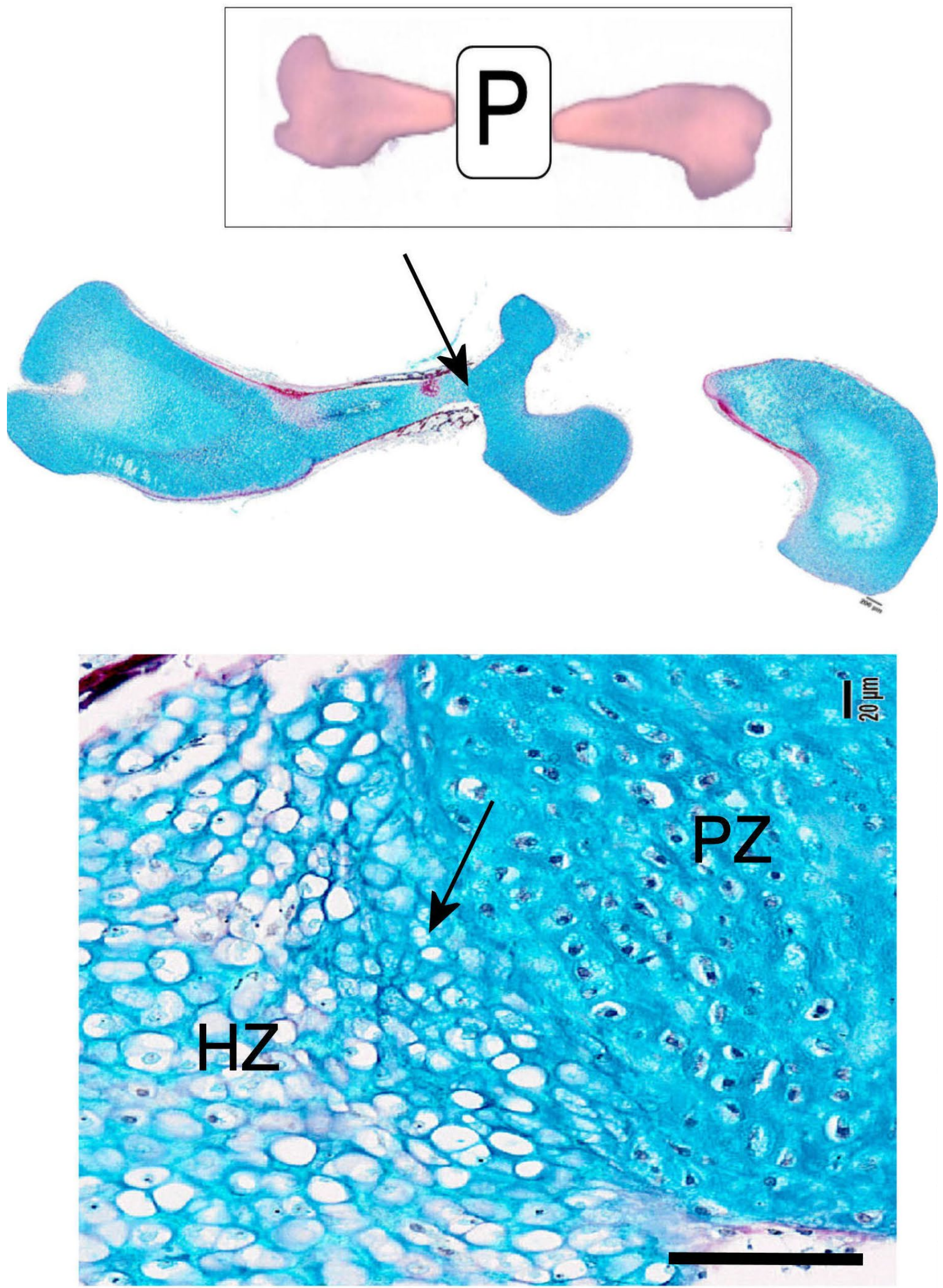

Fig. 7. Directional cues in chick growth plate regions. Implantation of proliferative zone region (P) favours integration on the left hand side of the host femur tissue, depending on orientation. HZ = hypertrophic region of host femur tissue, $\mathrm{PZ}=$ proliferative cells of implanted region. Arrows indicate areas of integration between implanted and host tissue. Scale bar $=100 \mu \mathrm{m}$. 


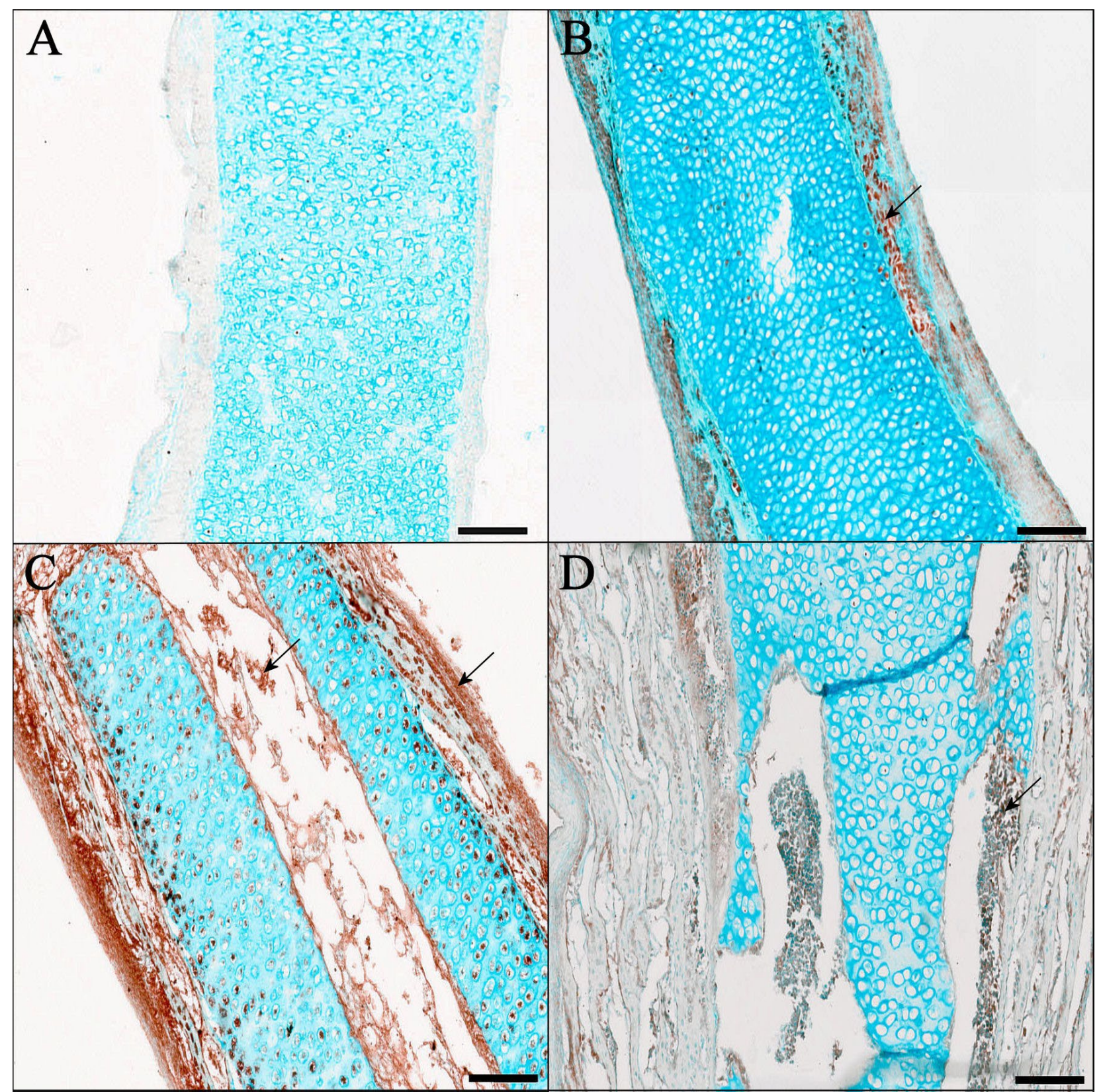

Fig. 8. Developing chick femora exhibit defined temporal and spatial expression patterns of the mesenchymal stem cell marker STRO-1. Expression of STRO-1 is absent from embryonic day 10 femora (A), but begins to appear within the diaphyseal bone collar at embryonic day 11 (B). Expression significantly increases within newly developing bone and marrow from embryonic day 12 to day 15 (C), but decreases in later development, with the limited expression restricted to the marrow spaces (D). Arrows indicate STRO-1 expression. Scale bar $=100 \mu \mathrm{m}$.

spatially-orientated multiple cell types in their natural matrix, there are also, as with all model systems, disadvantages. The lack of a blood supply ex vivo remains a clear drawback, since invasion of blood vessels is critical for nutrient diffusion, cell delivery and invasion of bone tissue into hypertrophic cartilage during the processes of endochondral ossification (Dai and Rabie, 2007; Mackie et al., 2008; Ortega et al., 2004). However, the combination of the ex vivo chick femur system with the CAM model enables blood vessel invasion into the ex vivo tissue, thus bringing the model one-step closer to an approximation of an in vivo situation. In addition, the lack of a blood supply provides a unique opportunity, as it enables the study of bone/cartilage development and formation processes without the complicated and additional processes initiated by the cells and factors of the vasculature.

Further disadvantages of the chick femur model are the differences in development and growth between avian and human bone, which raises questions about the relevance of these experimental observations to clinical strategies. Specific differences include the lack of a secondary ossification centre in embryonic avian femora, until after hatching and the absence of vascularisation of the primary cartilage prior to mineralisation (Nowlan et al., 2007). In mammals, the growth plate remains relatively constant in thickness due to similar rates of vascular invasion and resorption, whereas the chick growth plate markedly increases in thickness during embryonic development. 
Furthermore, the chick growth-plate is not as distinctly ordered as its mammalian counterpart and specialised regions not found in mammals can be identified within the hypertrophic zone (Roach, 1997). It should be noted, however, that cellular and signalling events occurring during bone growth and development are similar across both species. There is also the possibility to extend this model system into human foetal femora to confirm the relevance of observation from the chick model in a human situation. Overall, the advantages of the chick femur model outweigh the disadvantages of the system, and it remains a useful, cheap and easily manipulated model system.

\section{Future directions}

Chick limb organ culture systems have been used in the scientific research field since the 1920 s and continue to be used throughout a wide number of disciplines. Future directions for the model system include the introduction of exogenous cell populations into the chick femora, to enable the study of processes that would not normally be able to be examined in the system. For example, the microinjection of endothelial cells in combination with CAM technologies could be used to dissect the mechanisms of vascular formation and invasion in an ex vivo setting. Exogenous cells can be labelled with fluorescent trackers to permit assessment of cell migration within the tissue and the availability of GFP-expressing transgenic chick embryos would also allow assessment of host versus graft cell responses. The model also presents an opportunity for studying the mechanisms underlying niche development and stem cell fate, as demonstrated above with analysis of the spatial and temporal expression patterns of STRO1. Utilising such approaches it is possible to employ the chick femur model to examine and delineate the processes governing stem cell differentiation and to further elucidate the identity of mesenchymal/skeletal stem cells.

Use of the chick femur as a model of bone repair, by creating critical sized defects within the tissue, offers significant potential as a testing system for novel scaffold biomaterials and for development of niche microenvironments. Such scaffolds seeded with cells and/ or growth factors can be implanted into the chick femur defects and the cellular/tissue behaviour of the surrounding bone and cartilage assessed, thus enabling the study of skeletal regeneration ex ovo. Thus, the model serves to bridge the gap between simpler in vitro testing systems and complex, expensive in vivo models. In addition, the exciting developments of bioreactor technology provide a unique opportunity for simulating the mechanical forces experienced by skeletal tissue in vivo, bringing the model another step closer to mimicking the skeletal growth and regeneration processes that occur in vivo.

\section{Conclusions}

The ex vivo chick femur organotypic culture system represents a useful model with potential applications in a number of scientific fields. This approach to culturing and manipulating collective populations of cells within their natural extracellular matrix can provide crucial information on developmental and repair processes. Combination with other techniques, such as CAM systems, creation of bone defects, micromanipulation, microinjection and bioreactor technologies, further enhance the capacity of the model to recapitulate and manipulate in vivo processes. The chickfemur organ culture models have informed our knowledge on the complex processes of bone development and repair, and provide a high throughput, facile, inexpensive screening model for novel scaffold biomaterials free from the ethical concern surrounding in vivo models. Thus, the model offers significant potential as a test bed for scaffold, cell and growth factor therapies, while addressing the 3Rs of reduction, refinement and replacement and bridging the gap between facile in vitro cell systems and complex in vivo models. These many advantages of the ex vivo chick system, combined with recent and emerging technical developments in the field that further enhance and improve the model, suggest the embryonic chick model will continue to offer important contributions to the growing field of tissue regenerative medicine over the coming years.

\section{Acknowledgements}

This work was supported by the strategic longer and larger grant (sLOLA) from the Biotechnology and Biological Sciences Research Council, UK-grant number BB/ G010579/1, as well as partial funding from EU Biodesign (EU FP7). Technical support from Carol Roberts is gratefully acknowledged for work presented and useful discussions from all in the Bone and Joint Research Group and sLOLA collaborators Professors Kevin Shakesheff, Molly Stevens and Alicia El Haj, as well as discussions with Professors James Triffitt, Robert Brown and Tim Hardingham. We wish to confirm that there are no known conflicts of interest associated with this publication and there has been no significant financial support for this work that could have influenced its outcome.

\section{References}

Baiguera S, Macchiarini P, Ribatti D (2012) Chorioallantoic membrane for in vivo investigation of tissue-engineered construct biocompatibility. J Biomed Mater Res B Appl Biomater 100: 1425-1434.

Bilodeau K, Mantovani D (2006) Bioreactors for tissue engineering: focus on mechanical constraints. A comparative review. Tissue Eng 12: 2367-2383.

Bingham PJ, Raisz LG (1974) Bone growth in organ culture: Effects of phosphate and other nutrients on bone and cartilage. Calcif Tissue Res 14: 31-48.

Bock N, Riminucci A, Dionigi C, Russo A, Tampieri A, Landi E, Goranov VA, Marcacci M, Dediu V (2010) A novel route in bone tissue engineering: magnetic biomimetic scaffolds. Acta Biomater 6: 786-796.

Bolgen N, Yang Y, Korkusuz P, Guzel E, El Haj AJ, Piskin E (2008) Three-dimensional ingrowth of bone cells within biodegradable cryogel scaffolds in bioreactors at different regimes. Tissue Eng Part A 14: 1743-1750. 
Borges J, Tegtmeier FT, Padron NT, Mueller MC, Lang EM, Stark GB (2003) Chorioallantoic membrane angiogenesis model for tissue engineering: a new twist on a classic model. Tissue Eng 9: 441-450.

Botchwey EA, Pollack SR, Levine EM, Laurencin CT (2001) Bone tissue engineering in a rotating bioreactor using a microcarrier matrix system. J Bomed Mater Res 55: 242-253.

Boulland J-L, Halasi G, Kasumacic N, Glover JC (2010) Xenotransplantation of human stem cells into the chicken embryo. J Vis Exp 41: e2071.

Buschmann J, Welti M, Hemmi S, Neuenschwander P, Baltes C, Giovanoli P, Rudin M, Calcagni M (2011) Threedimensional co-cultures of osteoblasts and endothelial cells in DegraPol foam: histological and high-field magnetic resonance imaging analyses of pre-engineered capillary networks in bone grafts. Tissue Eng Part A 17: 291-299.

Buschmann J, Härter L, Gao S, Hemmi S, Welti M, Hild N, Schneider OD, Stark WJ, Lindenblatt N, Werner CML, Wanner GA, Calcagni M (2012) Tissue engineered bone grafts based on biomimetic nanocomposite PLGA/ amorphous calcium phosphate scaffold and human adipose-derived stem cells. Injury 43: 1689-1697.

Butler DL, Goldstein SA, Guilak F (2000) Functional tissue engineering: the role of biomechanics. J Biomech Eng 122: 570-575.

Cartmell SH, Dobson J, Verschueren SB, El Haj AJ (2002) Development of magnetic particle techniques for long-term culture of bone cells with intermittent mechanical activation. IEEE Trans Nanobioscience 1: 92-97.

Chen H, Wang CS, Li M, Sanchez E, Li J, Berenson A, Wirtschafter E, Wang J, Shen J, Li Z, Bonavida B, Berenson JR (2010) A novel angiogenesis model for screening anti-angiogenic compounds: the chorioallantoic membrane/feather bud assay. Int J Oncol 37: 71-79.

Chesnick IE, Fowler CB, Mason JT, Potter K (2011) Novel mineral contrast agent for magnetic resonance studies of bone implants grown on a chick chorioallantoic membrane. Magn Reson Imaging 29: 1244-1254.

Curtin P, Youm H, Salih E (2012) Three-dimensional cancer-bone metastasis model using ex-vivo co-cultures of live calvarial bones and cancer cells. Biomaterials 33: 1065-1078.

Dai J, Rabie ABM (2007) VEGF: an Essential Mediator of Both Angiogenesis and Endochondral Ossification. J Dent Res 86: 937-950.

David V, Guignandon A, Martin A, Malaval L, LafageProust MH, Rattner A, Mann V, Noble B, Jones DB, Vico L (2008) Ex vivo bone formation in bovine trabecular bone cultured in a dynamic $3 \mathrm{D}$ bioreactor is enhanced by compressive mechanical strain. Tissue Eng Part A 14: 117-126.

Dingle JT, Lucy JA, Fell HB (1961) Studies on the mode of action of excess of vitamin A. 1. Effect of excess of vitamin A on the metabolism and composition of embryonic chick-limb cartilage grown in organ culture. Biochem J. 79: 497-500.

Dingle JT, Fell HB, Goodman DS (1972) The effect of retinol and of retinol-binding protein on embryonic skeletal tissue in organ culture. J Cell Sci 11: 393-402.
Dobson J, Cartmell SH, Keramane A, El Haj AJ (2006) Principles and design of a novel magnetic force mechanical conditioning bioreactor for tissue engineering, stem cell conditioning, and dynamic in vitro screening. IEEE Trans nanobioscience 5: 173-177.

Eder C, Falkner E, Nehrer S, Losert UM, Schoeffl $\mathrm{H}$ (2006) Introducing the concept of the $3 \mathrm{Rs}$ into tissue engineering research. ALTEX 23: 17-23.

El Haj AJ, Cartmell SH (2010) Bioreactors for bone tissue engineering. Proc Inst Mech Eng H 224: 1523-1532.

El Haj AJ, Minter SL, Rawlinson SC, Suswillo R, Lanyon LE (1990) Cellular responses to mechanical loading in vitro. J Bone Miner Res 5: 923-932.

Falkner E, Eder C, Kapeller B, Froschl W, Schmatz C, Macfelda K, Losert UM (2004) The mandatory CAM testing of cells and scaffolds for tissue engineering: benefits for the three Rs of cooperation with the vaccine industry. Altern Lab Anim 32: 573-580.

Feflea S, Cimpean AM, Ceausu RA, Gaje P, Raica M (2012) Effects of antibodies to EG-VEGF on angiogenesis in the chick embryo chorioallantoic membrane. In Vivo 26: 793-797.

Fell HB (1969) The effect of environment on skeletal tissue in culture. Embryologia (Nagoya) 10: 181-205.

Fell HB, Dingle JT (1969) Endocytosis of sugars in embryonic skeletal tissues in organ culture. J Cell Sci 4: 89-103.

Fell HB, Mellanby E (1952) The effect of hypervitaminosis A on embryonic limb-bones cultivated in vitro. J Physiol 116: 320-349.

Fell HB, Robison R (1929) The growth, development and phosphatase activity of embryonic avian femora and limb-buds cultivated in vitro. Biochem J 23: 767-784.

Fell HB, Coombs RRA, Dingle JT (1966) The breakdown of embryonic (chick) cartilage and bone cultivated in the presence of complement-sufficient antiserum. Int Arch Allergy Appl Immunol 30: 146-176.

Friebova-Zemanova Z (1981) Formation of the chick mesonephros. 4. Course and architecture of the developing nephrons. Anat Embryol (Berl) 161: 341-354.

Ganan Y, Macias D, Garcia-Martinez V, Hurle JM (1993) In vivo experimental induction of interdigital tissue chondrogenesis in the avian limb bud results in the formation of extradigits. Effects of local microinjection of staurosporine, zinc chloride and growth factors. Prog Clin Biol Res 383A: 127-139.

Gellynck K, Parkar M, Buxton P (2007) CaP based in vivo delivery of ostegenic agonists in chick embryonic femora. Eur Cell Mater 14: 23.

Goldstein RS (2006) Transplantation of human embryonic stem cells to the chick embryo. In: Turksen K (ed) Human Embryonic Stem Cell Protocols. Humana Press, Totowa, pp 137-152.

Granet C, Laroche N, Vico L, Alexandre C, LafageProust MH (1998) Rotating-wall vessels, promising bioreactors for osteoblastic cell culture: comparison with other 3D conditions. Med Biol Eng Comput 36: 513-519.

Green D, Walsh D, Yang X, Mann S, Oreffo ROC (2004) Stimulation of human bone marrow stromal cells using growth factor encapsulated calcium carbonate porous microspheres. J Mater Chem 14: 2206-2212. 
Hall B (1981) Intracellular and extracellular control of the differentiation of cartilage and bone. Histochem J 13: 599-614.

Hamburger V, Hamilton HL (1992) A series of normal stages in the development of the chick embryo. Dev Dyn 195: 231-272.

Henstock JR, Rotherham M, Rose JB, El Haj AJ (2013) Cyclic hydrostatic pressure stimulates enhanced bone development in the foetal chick femur in vitro. Bone 53: 468-477.

Hillier LW, Miller W, Birney E, Warren W, Hardison RC (2004) Sequence and comparative analysis of the chicken genome provide unique perspectives on vertebrate evolution. Nature 432: 695-716.

Hughes S, Dobson J, El Haj AJ (2007) Magnetic targeting of mechanosensors in bone cells for tissue engineering applications. J Biomech 40 Suppl 1: S96-104.

Isachenko V, Mallmann P, Petrunkina AM, Rahimi G, Nawroth F, Hancke K, Felberbaum R, Genze F, Damjanoski I, Isachenko E (2012) Comparison of in vitroand chorioallantoic membrane (CAM)-culture systems for cryopreserved medulla-contained human ovarian tissue. PLoS One 7: e32549.

Kanczler JM, Barry J, Ginty P, Howdle SM, Shakesheff KM, Oreffo RO (2007) Supercritical carbon dioxide generated vascular endothelial growth factor encapsulated poly(DL-lactic acid) scaffolds induce angiogenesis in vitro. Biochem Biophys Res Commun 352: 135-141.

Kanczler JM, Sura HS, Magnay J, Green D, Oreffo RO, Dobson JP, El Haj AJ (2010) Controlled differentiation of human bone marrow stromal cells using magnetic nanoparticle technology. Tissue Eng Part A 16: 3241-3250.

Kanczler JM, Smith EL, Roberts CA, Oreffo RO (2012) A novel approach for studying the temporal modulation of embryonic skeletal development using organotypic bone cultures and microcomputed tomography. Tissue Eng Part C Methods 18: 747-760.

Kavlock KD, Goldstein AS (2008) Effect of pulsatile flow on the osteogenic differentiation of bone marrow stromal cells in porous scaffolds. Biomed Sci Instrum 44: 471-476.

Knothe Tate ML, Knothe U (2000) An ex vivo model to study transport processes and fluid flow in loaded bone. J Biomech 33: 247-254.

Kwon MS, Koo BC, Choi BR, Lee HT, Kim YH, Ryu W-S, Shim H, Kim J-H, Kim N-H, Kim T (2004) Development of transgenic chickens expressing enhanced green fluorescent protein. Biochem Biophys Res Commun 320: 442-448.

Lance-Jones C, Shah V, Noden DM, Sours E (2012) Intrinsic properties guide proximal abducens and oculomotor nerve outgrowth in avian embryos. Dev Neurobiol 72: 167-185.

Liu X, Wang X, Horii A, Wang X, Qiao L, Zhang S, Cui F-Z (2012) In vivo studies on angiogenic activity of two designer self-assembling peptide scaffold hydrogels in the chicken embryo chorioallantoic membrane. Nanoscale 4: 2720-2727.

Lokman NA, Elder AS, Ricciardelli C, Oehler MK (2012) Chick chorioallantoic membrane (CAM) assay as an in vivo model to study the effect of newly identified molecules on ovarian cancer invasion and metastasis. Int J Mol Sci 13: 9959-9970.

Lorda-Diez C, Montero J, Garcia-Porrero J, Hurle J (2010) Tgfbeta2 and 3 are coexpressed with their extracellular regulator Ltbp1 in the early limb bud and modulate mesodermal outgrowth and BMP signaling in chicken embryos. BMC Dev Biol 10: 69.

Mackie EJ, Ahmed YA, Tatarczuch L, Chen KS, Mirams M (2008) Endochondral ossification: How cartilage is converted into bone in the developing skeleton. Int J Biochem Cell Biol 40: 46-62.

Mauney JR, Sjostorm S, Blumberg J, Horan R, O’Leary JP, Vunjak-Novakovic G, Volloch V, Kaplan DL (2004) Mechanical stimulation promotes osteogenic differentiation of human bone marrow stromal cells on 3 -D partially demineralized bone scaffolds in vitro. Calcif Tissue Int 74: 458-468.

McCabe KL, Bronner-Fraser M (2008) Essential role for PDGF signaling in ophthalmic trigeminal placode induction. Development 135: 1863-1874.

McGrew MJ, Sherman A, Ellard FM, Lillico SG, Gilhooley HJ, Kingsman AJ, Mitrophanous KA, Sang $\mathrm{H}$ (2004) Efficient production of germline transgenic chickens using lentiviral vectors. EMBO Rep 5: 728-733.

McKinney MC, Kulesa PM (2011) In vivo calcium dynamics during neural crest cell migration and patterning using GCaMP3. Dev Biol 358: 309-317.

Milan JL, Planell JA, Lacroix D (2009) Computational modelling of the mechanical environment of osteogenesis within a polylactic acid-calcium phosphate glass scaffold. Biomaterials 30: 4219-4226.

Minina E, Wenzel HM, Kreschel C, Karp S, Gaffield W, McMahon AP, Vortkamp A (2001) BMP and Ihh/PTHrP signaling interact to coordinate chondrocyte proliferation and differentiation. Development 128: 4523-4534.

Nagchowdhuri PS, Andrews KN, Robart S, Capehart AA (2012) Versican knockdown reduces interzone area during early stages of chick synovial joint development. Anat Rec (Hoboken) 295: 397-409.

Ning TH, Chao CJ, Ying MG, Min X, Shan WF (2012) Preparation, characterization and anti-angiogenesis activity of endostatin covalently modified by polysulfated heparin. Pharmazie 67: 622-627.

Nowlan NC, Murphy P, Prendergast PJ (2007) Mechanobiology of embryonic limb development. Ann N Y Acad Sci 1101: 389-411.

O'Brien CA, Plotkin LI, Galli C, Goellner JJ, Gortazar AR, Allen MR, Robling AG, Bouxsein M, Schipani E, Turner CH, Jilka RL, Weinstein RS, Manolagas SC, Bellido $\mathrm{T}$ (2008) Control of bone mass and remodeling by PTH receptor signaling in osteocytes. PLoS ONE 3: e2942.

Ortega N, Behonick DJ, Werb Z (2004) Matrix remodeling during endochondral ossification. Trends Cell Biol 14: 86-93.

Poole AR, Hembry RM, Dingle JT (1974) Cathepsin $\mathrm{D}$ in cartilage: the immunohistochemical demonstration of extracellular enzyme in normal and pathological conditions. J Cell Sc 14: 139-161.

Pound JC, Green DW, Chaudhuri JB, Roach HI, Oreffo ROC (2006) Bioreactor culture of cartilage from mesenchymal populations. J Bone Joint Surg Br 88: 405. 
Rashidi H, Sottile V (2009) The chick embryo: hatching a model for contemporary biomedical research. Bioessays 31: 459-465.

Ribatti D (2008a) Chick embryo chorioallantoic membrane as a useful tool to study angiogenesis. In: Kwang WJ (ed) International Review of Cell and Molecular Biology. Academic Press, San Diego, Chapter 5, pp 181-224.

Ribatti D (2008b) The chick embryo chorioallantoic membrane in the study of tumor angiogenesis. Rom $\mathrm{J}$ Morphol Embryol 49: 131-135.

Roach HI (1990) Long-term organ culture of embryonic chick femora: A system for investigating bone and cartilage formation at an intermediate level of organization. J Bone Miner Res 5: 85-100.

Roach HI (1992a) Induction of normal and dystrophic mineralization by glycerophosphates in long-term bone organ culture. Calcif Tissue Int 50: 553-563.

Roach HI (1992b) Trans-differentiation of hypertrophic chondrocytes into cells capable of producing a mineralized bone matrix. Bone Miner 19: 1-20.

Roach HI (1997) New aspects of endochondral ossification in the chick: chondrocyte apoptosis, bone formation by former chondrocytes, and acid phosphatase activity in the endochondral bone matrix. J Bone Miner Res 12: 795-805.

Roach HI, Erenpreisa J, Aigner T (1995) Osteogenic differentiation of hypertrophic chondrocytes involves asymmetric cell divisions and apoptosis. J Cell Biol 131: 483-494.

Salem AK, Rose FRAJ, Oreffo ROC, Yang X, Davies MC, Mitchell JR, Roberts CJ, Stolnik-Trenkic S, Tendler SJB, Williams PM, Shakesheff KM (2003) Porous polymer and cell composites that self-assemble in situ. Adv Mater 15: $210-213$.

Salgado AJ, Coutinho OP, Reis RL (2004) Bone tissue engineering: state of the art and future trends. Macromol Biosci 4: 743-765.

Sang H (2004) Prospects for transgenesis in the chick. Mech Dev 121: 1179-1186.

Schlüter K-D (1999) PTH and PTHrP: similar structures but different functions. Physiology 14: 243-249.

Sikavitsas VI, Bancroft GN, Holtorf HL, Jansen JA, Mikos AG (2003) Mineralized matrix deposition by marrow stromal osteoblasts in $3 \mathrm{D}$ perfusion culture increases with increasing fluid shear forces. Proc Natl Acad Sci U S A 100: 14683-14688.

Silva BC, Costa AG, Cusano NE, Kousteni S, Bilezikian JP (2011) Catabolic and anabolic actions of parathyroid hormone on the skeleton. J Endocrinol Invest 34: 801-810.

Singh S, Wu BM, Dunn JC (2012) Delivery of VEGF using collagen-coated polycaprolactone scaffolds stimulates angiogenesis. J Biomed Mater Res A 100: 720 727.

Sloan AJ, Taylor SY, Smith EL (2012) Organotypic mandibular cultures for the study of inflammatory bone pathology. In: Davies J (ed) Replacing Animal Models, John Wiley \& Sons, Hoboken, pp 159-166.
Smith EL, Locke M, Waddington RJ, Sloan AJ (2010) An ex vivo rodent mandible culture model for bone repair. Tissue Eng Part C Methods 16: 1287-1296.

Smith EL, Kanczler JM, Roberts CA, Oreffo RO (2012) Developmental cues for bone formation from parathyroid hormone and parathyroid hormone-related protein in an ex vivo organotypic culture system of embryonic chick femora. Tissue Eng Part C Methods 18: 984-994.

Stacey DW, Allfrey VG (1976) Microinjection studies of duck globin messenger RNA translation in human and avian cells. Cell 9: 725-732.

Steffens L, Wenger A, Stark GB, Finkenzeller G (2009) In vivo engineering of a human vasculature for bone tissue engineering applications. J Cell Mol Med 13: 3380-3386.

Stern CD (2004) The chick embryo - past, present and future as a model system in developmental biology. Mech Dev 121: 1011-1013.

Stern CD (2005) The chick: a great model system becomes even greater. Dev Cell 8: 9-17.

Sys G, Van Bockstal M, Forsyth R, Balke M, Poffyn B, Uyttendaele D, Bracke M, De Wever O (2012) Tumor grafts derived from sarcoma patients retain tumor morphology, viability, and invasion potential and indicate disease outcomes in the chick chorioallantoic membrane model. Cancer Lett 326: 69-78.

Takahashi K, Shanahan M, Coulton L, Duckworth T (1991) Fracture healing of chick femora in tissue culture. Acta Orthop Scand 62: 352-355.

Tickle C (2004) The contribution of chicken embryology to the understanding of vertebrate limb development. Mech Dev 121: 1019-1029.

Tufan AC, Satiroglu-Tufan NL (2005) The chick embryo chorioallantoic membrane as a model system for the study of tumor angiogenesis, invasion and development of anti-angiogenic agents. Curr Cancer Drug Targets 5: 249-266.

Van Hoof J, Harrisson F, Andries L, Vakaet L (1986) Microinjection of glycosaminoglycan-degrading enzymes in the chicken blastoderm. An ultrastructural study. Differentiation 31: 14-19.

Vargas GE, Mesones RV, Bretcanu O, Lopez JM, Boccaccini AR, Gorustovich A (2009) Biocompatibility and bone mineralization potential of 45S5 Bioglass-derived glass-ceramic scaffolds in chick embryos. Acta Biomater 5: 374-380.

Weissmann G, Dingle J (1961) Release of lysosomal protease by ultraviolet irradiation and inhibition by hydrocortisone. Exp Cell Res 25: 207-210.

Weston PD, Barrett AJ, Dingle JT (1969) Specific inhibition of cartilage breakdown. Nature 222: 285-286.

Wichterle H, Peljto M, Nedelec S (2008) Xenotransplantation of embryonic stem cell-derived motor neurons into the developing chick spinal cord. Methods Mol Biol 482: 171-183.

Wolpert L (2004) Much more from the chicken's egg than breakfast - a wonderful model system. Mech Dev 121: 1015-1017.

Yang X, Whitaker M, Sebald W, Clarke N, Howdle S, Shakesheff K, Oreffo R (2004) Human osteoprogenitor 
bone formation using encapsulated bone morphogenetic protein 2 in porous polymer scaffolds. Tissue Eng 10: 1037-1045.

Yu X, Botchwey EA, Levine EM, Pollack SR, Laurencin CT (2004) Bioreactor-based bone tissue engineering: The influence of dynamic flow on osteoblast phenotypic expression and matrix mineralization. Proc Natl Acad Sci USA 101: 11203-11208.

Zabielska K, Lechowski R, Krol M, Pawlowski KM, Motyl T, Dolka I, Zbikowski A (2012) Derivation of feline vaccine-associated fibrosarcoma cell line and its growth on chick embryo chorioallantoic membrane - a new in vivo model for veterinary oncological studies. Vet Res Commun 36: $227-233$.

\section{Discussion with Reviewer}

Reviewer I: Influence of mechanical forces is clearly a contributing factor in natural cell function in bone development and mimicking that, through the use of bioreactors for cell cultures, is well established. It is not clear however, from the manuscript how a bioreactor design can be developed for the chick femur system. Would such a bioreactor design be the same as that used with cells/ scaffolds or bone explants or would specific changes need to be made? Which type would be preferable?

Authors: A recent study by Henstock et al. (2013) used a custom-designed bioreactor to apply hydrostatic forces across the organotypic chick femur cultures, and indicated an increase in bone formation and mineralisation in response to cyclical, but not static, pressures. The cycling frequency was critical to inducing increased skeletal tissue formation, whereas the magnitude of the force applied did not significantly influence the amount of bone. Therefore it appears that a cycling hydrostatic bioreactor is most suited to stimulating osteogenesis in the ex vivo chick system. 